DOI https://doi.org/10.18551/rjoas.2016-12.17

\title{
INFLUENCE OF LEADERSHIP TOWARDS WORKING PERFORMANCE MEDIATED WITH MOTIVATION: A STUDY ON THE IMPLEMENTATION OF «PEMBERDAYAAN KELURAHAN AND KAMPUNG» PROGRAM IN JAYAPURA
}

\author{
Lolowang Nansi Lidya*, Troena Eka Afnan, Djazuli Atim, Aisjah Siti
}

Faculty of Economics and Business, University of Brawijaya, Indonesia

*E-mail: nansi.lidya18@gmail.com

\begin{abstract}
Kampung and kelurahan in Jayapura is a public organization that becomes the front-liner in providing public service. Village and village organization requires strong leadership and motivation to support improving performance. The study aims at examining and analyzing the influence of leadership on working performances, and motivation at work as a medium which resulted in the influence leadership towards working performances. It was conducted in 39 villages and urban villages in Jayapura. The population of the study was 96 permanent employees working at the village and village in Jayapura. All of the population was selected as the respondents and therefore, the study was categorized as census study. The data analysis method used was Partial Least Square. The findings show that results showed that direct leadership did not have significant influence towards working performances and motivation at work is the perfect medium so that leadership has significant influence towards working performances.
\end{abstract}

\section{KEY WORDS}

Leadership, employee's motivation, working performances.

Based on the 1999 Decree number 22 about the Regional Government and its amendment the 2004 Decree number 32, the regional government has rights to organize and manage their own government affairs for the sake of efficient and effective implementation of good local governance. It refers to local government autonomy. The 2004 Decree number 32 is related to kelurahan. Article 127 paragraph (1) of the decree stated that kelurahan is established within kecamatan using the government regulation as the foundation. Furthermore, paragraph (9) consists of the implementation of the provisions stated in paragraph (2), (3), (4), (5), (6) and (7), established by peraturan bupati and walikota in accorandce with the legislation.

Process of designing programs for village and sub-district should basically be started from the lowest level that is from the public and for the public by paying attention to or prioritizing the public need. Different organizations should be involved to design these programs so that they become public consensus. The programs will later be submitted to the community consultation on development planning (Musyawarah Perencanaan Pembangunan) at district-level and then to the local government agency (SKPD). These eventually will become a government program that becomes obligatory for the local government to apply.

Village and sub-district government has essential role in implementation of pemberdayaan desa dan kelurahan program. However, as the agent responsible for carrying out the program, human resources in the village and sub-district government is lacking in terms of numbers and quality. The human resources have yet had sufficient commitment to achieve goals of development. Unfortunately, in reality there are some empowerement programs that have yet been executed well due to particular issues.

Fluctuating number of poverty is the indicator of unsuccessful implementation of the public empowerment programs; such programs have yet shown significant outcome. As the consequence, the poverty level in Jayapura does not decrease from year to year. Leadership in the villages/sub-districts level has strategic role to empower human resources so that they 
carry out their function and tasks well. Hill and Caroll (1997) stipulated that leadership referred to an ability to encourage individuals (two or more people) to work together to carry out activities that lead to achievement of common purpose.

Jayapura is unique because there are some villages in the city. The government system consists of two different systems namely Indonesian government system; it is constitutional and a head of village becomes the leader and indigenous, non-formal government system where an Ondoafi becomes the leader.

In carrying out public service, employees (bureaucrats or government apparatus) had yet been able to carry out their responsibility. The government apparatus had several characteristics that resulted in public reluctance to deal with the bureaucracy (Siagian, 1994) namely 1) apathy, 2) brush, 3) coldness, 4) condescension, 5) robotics, 6) role book, and 7) run-around. Heads of village/ sub-district should have leadership quality because qualified leader is highly committed and these will encourage his/her employees to work well. Motivated leaders and employees will help villages/sub-districts to achieve their vision, mission and goals as well as realize the implementation of pemberdayaan desa dan kelurahan program.

An organization will be a successful one when its employees fulfill their main responsibility, are highly motivated, willing to go the extra mile, help each other, give advice to one another, participate actively, provide extra service to customers, and are willing to use his time effectively.

Success of a leader is determined by his/ her attitude, personality or characteristics. Based on the idea, there is an assumption that successful leader is closely related to his or her personal entity. The leader's personal entity is individual quality with various traits, attitude or characteristics the individual has, which according to Siagian (1994: 75-76 a) the abilities or traits referred to broad general knowledge, inquisitive nature, and the ability to grow and develop).

Based on the background of the study, there is a need to analyze and evaluate whether leadership and motivation can increase working performance of employees in the villages/sub-districts in Jayapura or not.

\section{REVIEW OF LITERATURE}

Studies analyzing the causal relationship between leadership and working performance have been carried out continuously for example the studies conducted by Sharkie, 2009; Cools, 2010; Salman, 2011; Cheng-Kang and Chuan-Yin, 2011; and Xu, et al 2013. Those showed leadership had significant, positive influence towards working performance. Working performance increased when leaders had particular capacity that met employee's expectations for instance high integrity and the ability to direct individuals within organization.

Studies analyzing the effect of leadership towards working performance through working motivation was conducted in a construction company where 118 from the total 187 responses became the source of data. Working performance was illustrated as the performance of each of the project managers. The findings showed that leadership had influence in improving working respective projects, the results showed that the leadership was responsible for improving working performance through motivation as the mediating role (Li, et al., 2012; Cools, 2010).

Leadership was the use of non-coercive influence to establish purpose of groups or organizations, motivate behavior that helped achieving the purpose and defined the culture of the group or organizations (Griffin, 2004). Leadership was an ability to handle other people in order to achieve maximum result with minimum friction and high collaboration; leadership is creative and guided force of passion and morale.

Hersey and Blanchard (2005) stated the the situational theory referred to an approach that focused on huge attention towards characteristics of employees to decide suitable leadership behavior. The model explained that managers should adjust their leadership behavior in response to various characteristics their employees had such as their expectation, experience, expertise, and willingness to accept responsibility. Motivation was a 
process that explained strength, direction, and persistence of a person in an attempt to achieve goals (Robbins and Judge, 2013). Motivation as driving force was intended as a natural urge to satisfy and maintain life. Motivation was collection of behaviors which provided the foundation for an individual to act in a manner that was directed toward a specific goal. Based on the elaboration, it was concluded that motivation was the impulse an individual had to behave and act in order to satisfy and maintain life which is directed towards the achievement of particular goals.

Robbins and Judge (2013) explained that motivation was a process that explained individual strength, direction and tenacity to achieve certain goals. In general, motivation was related to efforts of which purpose was to achieve goals.

\section{CONCEPTUAL FRAMEWORK}

Conceptual framework described relationship among variables in the study. The correlation among the variables was based on the leadership, organization and culture as well as motivation theories and also the findings of the previous studies related to the influence of leadership and motivation towards performance. The conceptual framework of the study was described in the following figure.

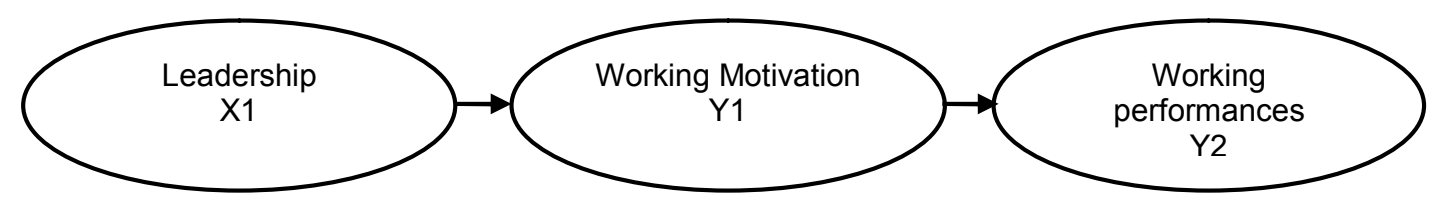

Figure 1 - Conceptual Framework

Hypotheses. Based on the findings of the studies conducted by Xu, Zhong (2013), Sharkie (2009), Cools (2010), and Salman (2011) that leadership had positive, significant influence towards working performances. Working performances would increase when a leader had certain capacity that met expectation of employees, high integrity, and ability to delegate tasks to the employees. However, another study revealed that leadership could not improve the performance of the employees (Minh Ha \& Nguyen; 2014) since they should be mediated by working satisfaction (Yang et al, 2012). It indicated a gap and therefore, the first hypothesis was:

H1. Leadership had influence towards working performances.

Previous study analyzed the influence of leadership towards working performances using working motivation. The setting was a developer and from 187 responses, there were 118 responses used in the data analysis. Working performances was illustrated as the performamnce of each of the project managers. The findings showed that leadership had influence towards the improvement in working performances through motivation as the medium ( $\mathrm{Li}$, et al, 2012; Cools, 2010). Therefore the second hypothesis was:

$\mathrm{H} 2$. Working motivation has mediating role in the influence of leadership towards working performances.

Operational Definitions:

Leadership (X1). Leadership referred to using non-coercive influence to achieve purpose of groups or organizations, encourage particular behavior to achieve the purpose and help defining the culture of group or organization. The indicators of leadership referred to those of Drucker (1996); McShane and VinGlinov (2008), Hayati and Caniago (2012), and Yang, et al (2011), which consisted of personal, leadership and organizational mastery/ ability.

Motivation (Y1). Vroom (1964)'s cognitive theory of motivation explained why an individual will not do an activity he or she is incapable of, even though the individual yearns for the outcome. The indicators for motivation referred to those of Vroom namely expectation, instrumental and valency. 
Working performances (Y2). Working performance was individual achievement in carrying out his/her duty. It would encourage achievement of company's visions (Sutrisno, 2010). The indicators of working performances in the study were those developed by McNesse (2009), namely: quality and quantity of work; persistence and durability; discipline and attendance; ability to work in groups; being careful while working; responsibility; initiative.

Methodology. The setting of the study was 39 kampungs (villages) and kelurahans (sub-districts) in 5 districts in Jayapura, namely 1) Jayapura Utara, 2) Jayapura Selatan, 3) Abepura, 4) Heram, and 5) Muara Tami. The researchers were familiar with the area so that access to information was easier. The subjects were all employees of the villages and subdistricts in Jayapura that carried out Pemberdayaan Kampung program. The data collection lasted between January to March 2015.The data analysis method was PLS (Partial Least Square) using the SmartPLS 2.0 M3 program (Ghozali, 2011a:18). The analysis was quantitative analysis.

\section{FINDINGS AND DISCUSSION}

Hypothesis 1: Improving leadership resulted in improving working performances.

The analysis showed that the coefficient showing direct relationship between leadership and working performances was -0.027 and $p$-value of 0.745 . P-value higher than 0.05 indicated that leadership did not have significant influence towards working performances. Therefore, hypothesis 1 was rejected.

Hypothesis 2: Improving leadership may increase working performances using employee's motivation as the mediating variable.

The findings of Sobel analysis described that the level of significance showing indirect relationship between leadership and working performances through motivation was 0.021 . Sobel test results lower than 0.05 indicated that the motivation was mediating the relationship between leadership and working performances. Therefore, hypothesis 2 was accepted.

The findings gave an overview that working motivation was the perfect medium that resulted in the correlation between leadership and working performances.

Leadership owned by a leader can encourage employees to have higher working motivation and carry out their duty well. Morale of the employees were able to give direction to carry out a good job, a job well done can improve the work of employees. High-motivated employees work better and achieve better result simultaneously. Giving motivating to employees should become major concern/ agenda of leaders of organization. Once the leaders can improve their employees' motivation, the employees would perform better job. The implementation of leadership in the villages/ sub-districts has yet been optimum, as represented by the average score of leadership of 3.81. The figure showed that the leadership applied so far has yet involved sufficient organizational skills. The lowest aspect of leadership is organizational skills with the average score of 3.72 . $7.29 \%$ respondents stated that they strongly disagreed or disagreed with the type of leadership applied by the head of the villages/ sub-districts. It indicated the lack of organizational skills the leaders had. The heads of the villages / sub-districts in Jayapura had yet been able to influence other people. In other words, they had yet been able to direct and give guiandce to their employees so that they would carry out their duty and obligations as they were supposed to.

The findings of the study did not corroborated with those of House (1971) that leadership would result in working performances. On the other hand, they corroborated with the findings of Yang et al (2012)'s study that leadership did not affect working performances. Their study mentioned that the implementation of leadership carried out by the head of organization did not result in working performances.

Intrinsic motivation will encourage an individual to work harder voluntarily in order to achieve purpose of organizations (Robbins, 2001). George and Jones (2002) and Robbins (2001) showed that motivation would increase performance. Based on Schein (1997) and Robbins (2001), and George and Jones (2002), it was concluded that working motivation 
may function as medium of leadership towards working performances. Sobel testing can be used to analyze indirect correlation between leadership towards working motivation. The test showed that the level of significance that showed the correlation between the two variables was 0.021 ; it meant employee's motivation was a medium that resulted in the influence of leadership towards working performances. Since leadership did not have influence towards working performances, employee's motivation was then the perfect medium to generate the influence of leadership towards performance. It showed that leadership could not resulted in working performances directly; yet, leadership may result in strong working motivation for the employees that eventually affected their working performance.

The findings were in line with Barbuto (2005)'s leadership theories that leadership did not generate performance directly; instead leadership resulted in motivation that generated working performance. Previous studies revealed that employee's motivation mediated between leadership and working performance. The findings of the study developed those of the previous studies conducted by Li, et al (2012), Ahmad (2009), Valensi E., (2008), Arthur (2003), Hayati and Caniago (2012), and Cools (2010). They stated that employee's motivation mediated the influence of leadership towards working performance.

Limitation of the Study. The study was conducted in the public organizations located in the village and sub-districts in Jayapura. The subjects of the study had different characteristics from other villages/ sub-districts in Papua. As the consequence, the findings of the study may not be able to represent conditions in other municipalities in Papua.

\section{CONCLUSION AND SUGGESTIONS}

From the findings and discussion in the previous section, some conclusions can be drawn as follows: leadership has pivotal role within organization so that individual's activity meets expectation of organization. Based on the findings of the study, leadership in villages/sub-districts in Jayapura does not have direct influence towards working performances; motivation is drive employees have to carry out their duty well. Employee's motivation is the perfect medium that results in significant influence of leadership towards working performances. Leadership may not have direct influence towards working performances; however, motivation can increase their performance.

From the conclusions, several suggestions can be made as follows: leadership in village and sub-district in Jayapura needs some improvement in order to generate better performance and encourage employees to fulfill their responsibilities. The type of leadership to improve is organizational skills; future researchers should involve more individuals as subjects of studies for example employees working for the city and provincial government of Papua. Future researchers should also involve more mediating variables such as working satisfaction. By involving more variable, it is expected that the findings may better represent the need of organizations in the village and sub-districts in Jayapura.

\section{REFERENCES}

1. Ahmad, K. (2009). Leadership and Work Motivation from the Cross cultural perspective, IJCOMA Vol. 19, No.1, 2009 pp 72-81.

2. Arthur, M.B. (2003). The motivational effects of charismatic leadership. A self concept based theory. Organizational Science. Vol. 4, pp. 577-94.

3. Barbuto, J.E. (2005). Motivation and Transactional, Charismatic, and Transformational Leadership: A Test Antecedents. Journal of Leadership \& Organizational Studies, Vol. 11, No. 4, pp. 26-40.

4. Cools, K. (2010). The leadership effects of performance measurement and culture organisation compensation on motivation: An empirical study de economic. p.303.

5. Drucker P. F. (1996). The Leader of The Future. The Drucker Fondation. New York

6. George, J.M. \& Jones, G.R. (2002). Understanding \& Managing organizational Behavior, $3^{\text {rd }}$ ed. New Jersey: Pearson Education Inc.

7. Ghozali, I. (2011). Aplikasi Analisis Multivariate Dengan Program IBM SPSS 19 (edisi 
kelima). Semarang: Universitas Diponegoro

8. Griffin, R.W. (2004). Manajemen, Edisi 7. Penerbit Erlangga, Jakarta.

9. Hayati, K. \& Caniago. (2012). Islamic work ethic: The Role of Intrinsic Motivation, Job Satisfaction, Organizational Commitment and Job Performance. Procedia, Social and Behavioral Science, 65 (2012) 272-277.

10. Hersey, P. \& Blanchard, K. (2005). Manajemen Perilaku Organisasi: Pendayagunaan Sumber Daya Manusia. Jakarta: Erlangga.

11. Hill, T. and Carol, S.J. (1997). Organisational Theory and Maanagement: A Macro Approch. John Wiley and Sons Inc., New York.

12. Li, Y.T., Chuan-hoo, T., Hock-Hai. (2012). Leadership characteristic and developers, motivation in open source software development. Information and Management.

13. McNeese-Smith, D. (2009). Increasing Employee Productivity, Job Satisfaction, and Organizational Commitment. Hospital \& Health Services Administration, 2(41), pp. 160175.

14. McShane, S.L. and Von Glinow, M.A. (2000). Organizational Behavior. Irwin/McGraw-Hill. Burr Ridge, IL.

15. Minh Ha, N. and Nguyen, T.V.H. (2014). The Influence of Leadership behaviors on Employee Performance in the Context of Software Companies in Vietnam. Advances in Management \& Applied Economics, vol. 4 No. 3, 2014, 157-171. ISSN: 1792-7544 (print version) 1792-7552 (online).

16. Robbins, S.T. (2001). Basic Motivation Concepts. Organizational Behavior, Prentice Hall, New Jersey, pp $155-209$, ch.6

17. Robbins, S.P. and Judge, T. (2013). Organizational Behavior. Boston: Pearson.

18. Salman, Z. (2011). Leadership Styles and Employee Performance (A case Study of Shakarganj Mills Limited Jhang Pakistan). Interdisciplinary Of Contemporary Research In Business, ijcrb.webs.com. Vol. 3, No.6, October 2011.

19. Schein, E.H. (1997). Organizational Culture and Leadership. Jossey-Bass, San Fransisco.

20. Sharkie, R. (2009). Trust in Leadership is vital for Employee Performance, Management Research News, Vol. 32, No. 5, 2009.

21. Shaw, J.D. (2005). A leadership behavior and motivate: an examination of its effect on the internalization process. Academy of Management Journal (45). pp. 12-17

22. Siagian, S.P. (1994). Manajemen Sumber Daya Manusia, Kepemimpinan dan Perilaku Administrasi. Jakarta: Bumi Aksara.

23. Solimun. (2008). Memahami Metode Kuantitatif Mutakhir Structural Equation Modelling and Partial Least Square, Malang. Program Statistika FMIPA Universitas Brawijaya.

24. Sutrisno, E. (2010). Manajemen Sumber Daya Manusia. Jakarta: Kencana Prenada Media Group

25. Xu, D., Xiao., W., Yan, X. (2013). The Impact of Subtitutes for Leadership on Job Satisfaction and Performance. Social Behavior and Personality, 4(41). pp. 675-686.

26. Yang, Li-Ren; Yen, Hsiu-Feng and Chiang, Yu-Fu. (2012) A framework for assessing impacts of leadership competency on police project performance, Mediating role on job satisfaction and moderating role of project type. International Journal of Police Strategies \& Management, Vol. 35 No.3, pp 528-550. 